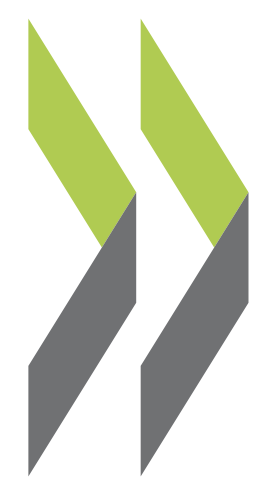

OECD Economics Department Working Papers No. 635

Quantifying the Effect of Financial Conditions on US Activity

Stéphanie Guichard, David Turner 
Organisation de Coopération et de Développement Économiques

Organisation for Economic Co-operation and Development

08-Sep-2008

ECONOMICS DEPARTMENT

English - Or. English

QUANTIFYING THE EFFECT OF FINANCIAL CONDITIONS ON US ACTIVITY

ECONOMICS DEPARTMENT WORKING PAPERS No. 635

By

Stéphanie Guichard and David Turner

All OECD Economic Department Working papers are available on the OECD website at www.oecd.org/eco/working_papers

JT03250152

Document complet disponible sur OLIS dans son format d'origine

Complete document available on OLIS in its original format 
TABLE OF CONTENTS

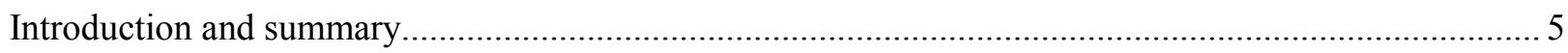

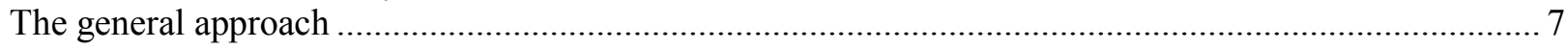

Econometric estimations underlying the construction of the financial conditions index .......................... 7

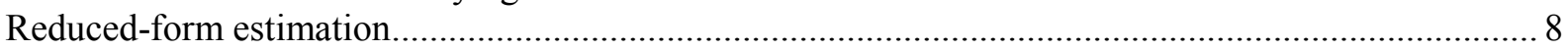

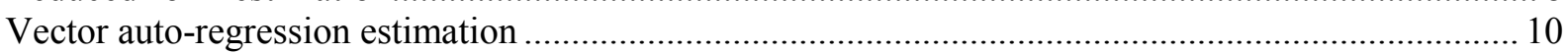

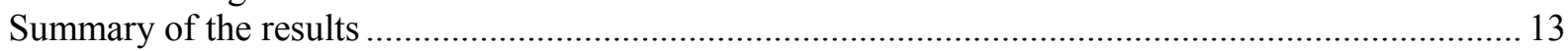

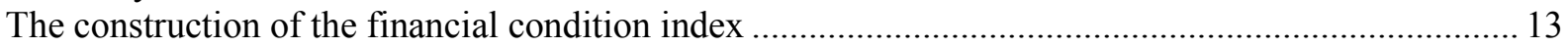

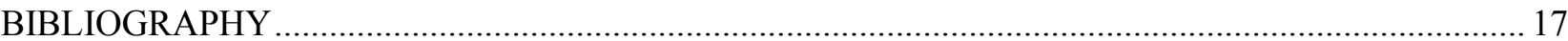


ECO/WKP(2008)43

\section{ABSTRACT/RÉSUMÉ \\ Quantifying the effect of financial conditions on US activity}

This paper constructs a broad measure of financial conditions for the United States which suggests that since the onset of the credit crisis there has been a marked tightening in financial conditions, despite a substantial easing of policy rates and a depreciation of the dollar. This measure of overall financial conditions includes interest rate spreads for riskier borrowers and a survey measure of the tightness of bank lending standards, which have been the main drivers behind the tightening in financial conditions. Indeed, recent data suggest that the trend deterioration in overall financial conditions has continued into the second half of 2008. The effect of the tightening in overall financial conditions already experienced may subtract $13 / 4$ per cent from GDP over the next four to six quarters. Not only have financial conditions continued to worsen, but much of the impact on the real economy has yet to be felt.

JEL Classification: E32, E44, E47, E51

Keywords: Financial conditions index; interest rate spreads; credit crunch; credit channel; macro-financial linkages

$* * * * *$

Une mesure de l'impact des conditions financières sur l'activité aux États-Unis.

Ce papier propose une mesure des conditions financières au sens large pour les États-Unis suggérant que depuis le début de la crise du crédit, les conditions financières se sont fortement resserrées malgré la baisse substantielle des taux directeurs et la dépréciation du dollar. Cette mesure des conditions financières au sens large inclut les primes de risques supportées par les emprunteurs les plus risqué et les résultats d'une enquête sur le caractère plus ou moins restrictif de l'accès au crédit bancaire. Ces derniers ont été les principaux facteurs conduisant á un durcissement des conditions financières. Les informations les plus récentes suggèrent que les conditions financières au sens large ont continué á se durcir au cours de la seconde moitié de 2008. L'effet du durcissement qui a eu lieu jusqu'à présent pourrait retirer jusqu'á $13 / 4$ pour cent de PIB au cours des quatre à six prochains trimestres. Ainsi, non seulement les conditions financières continuent á se durcir mais une large part de l'impact sur l'économie réelle reste á venir.

JEL Classification: E32, E44, E47, E51

Mots-clés: Indice des conditions financières; écarts de taux d'intérêt; contraction du crédit; canal du crédit; relations macro-financières

Copyright, OECD, 2008

Application for permission to reproduce or translate all, or part of, this material should be made to : Head of Publication Service, OECD, 2 rue André-Pascal, 75775 Paris, Cedex 16, France. 
ECO/WKP(2008)43 
ECO/WKP(2008)43

\section{QUANTIFYING THE EFFECT OF FINANCIAL CONDITIONS ON US ACTIVITY ${ }^{1}$}

\section{Introduction and summary}

1. In the summer of 2007, OECD financial markets were hit by a general re-pricing of risk triggered by mounting problems in the US sub-prime mortgage sector (OECD, 2007; OECD, 2008). This financial turmoil generated strong headwinds to growth in the OECD and particularly in the United States. The repricing of risk progressively spread from opaque securitised products to other assets classes (Figure 1): equity prices have fallen, particularly for financial sector companies; corporate bonds have registered steep increases in the premium paid by riskier borrowers; and bank credit default swap (CDS) rates have widened substantially. Although the situation showed some signs of improvement following the Bear Stearns episode in March 2008, spreads and CDS rates have increased again, reaching new highs in August. Meanwhile, financial sector worries continue to weigh on equity prices. Banks in the United States and Europe are particularly affected and many have already reported sizeable write-downs and credit losses, amounting so far to an estimated $\$ 503$ billion and so have seen their capital cushions shrink sharply. ${ }^{2}$ In response banks have sought fresh capital, tried to transfer some of their bad assets to other agents, and also tightened credit standards to both households and businesses. According to the US Federal Senior Loan Officer Opinion Survey of bank lending practices, over the year to July 2008 the net proportion of banks which have reported tightening credit standards to large and medium firms has risen from 7.5 to $57.5 \%$, with both the more recent figure and the change in conditions over the last year being close to historical highs.

2. However, other measures of financial conditions, particularly interest rates on government paper, have eased; interest rates on government bonds in most major OECD countries have fallen due to a flight to quality and most central banks have responded to the prospect of weaker activity by either cutting short-term policy rates or postponing increases that were previously widely anticipated. In the United States since the onset of the turmoil the federal funds rate has been cut by 325 basis points and long-term government bond rates have fallen about 100 basis points. In addition, and notwithstanding a recent rally, there has been a further substantial depreciation of the dollar since the onset of the turmoil, which should help to boost exports and support growth in the United States.

\footnotetext{
1. An earlier version of this work was presented in the June 2008 OECD Economic Outlook. We would like to thank Mike Kennedy, Jorgen Elmeskov and Jean-Luc Schneider for comments on earlier work as well as Romain Duval, Andrea de Michelis, Luke Willard, David Haugh and Vincent Koen. Thanks also to Anne Eggimann, Lise Perrault and Patrice Ollivaud for help in preparing the document and for statistical support.

2. Data is from Bloomberg as at 20 August 2008 at which time the US banks accounted for $48 \%$ of the losses and European banks for $45 \%$.
} 
Figure 1. The financial environment has tightened

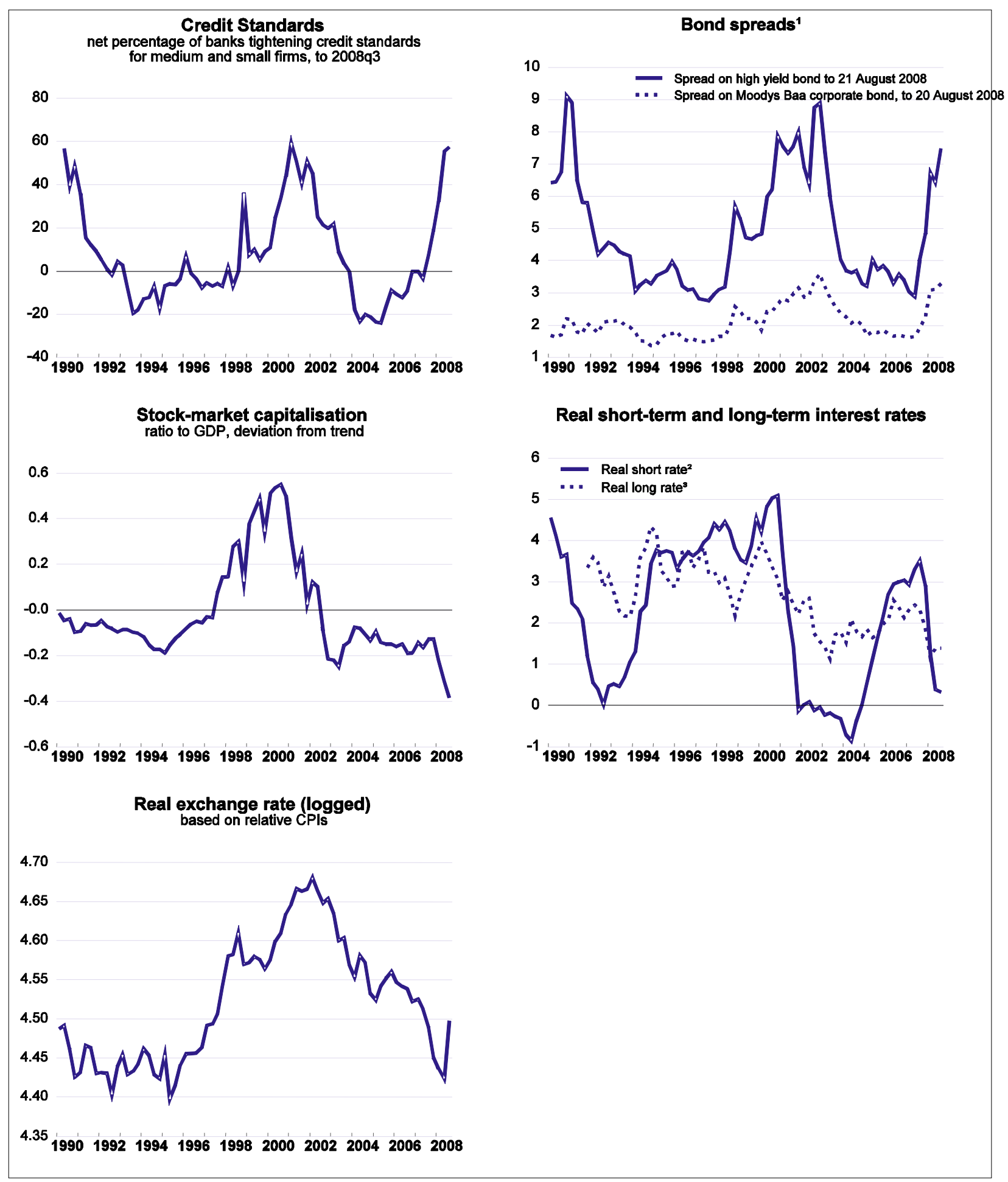

1. Spreads calculated relative to 10 -year government bond.

2. Real short rates are the 3-month Treasury bill rate relative to the inflation rate based on the core consumers' expenditure deflator.

3. Real long-rates are the 10-year government bond relative to the expected inflation rate over the next ten years according to the Survey of Professional Forecasters by the Federal Reserve Bank of Philadelphia.

Source: US Federal Senior Loan Officer Opinion Survey; Datastream; Federal Reserve of Philadelphia; OECD Economic Outlook 83 database; and authors' calculations. 
3. This paper proposes a broad indicator of financial conditions in the United States that synthesises all of these factors by weighting together their influences on growth. ${ }^{3}$ One novelty is the inclusion in this indicator of a survey measure of the tightness in non-price credit bank lending standards. The focus is on the United States, not only because this is where financial headwinds may be greatest, but also because it has a wide range of financial market variables with a sufficiently long time series for estimation purposes.

4. The main findings of the paper are as follows:

- Non-price credit standards have a large effect on GDP growth in the United States, which is both statistically robust across a number of different specifications and methodologies and meaningfully large economically.

- Broad financial conditions have tightened significantly since summer 2007, despite lower real short- and long-term interest rates on government paper and the real effective depreciation of the dollar. Moreover, the trend deterioration in overall financial conditions appears to be continuing into the third quarter of 2008: bank lending standards have tightened further; spreads for riskier borrowers have widened; and there has been a limited reversal of the dollar's depreciation.

- The overall negative impact on GDP implied by the tightening of the index to date is equivalent to an increase in real long-term (government bond) interest rates of close to 280 basis points.

\section{The general approach}

5. Monetary condition indices are often computed to gauge the impact of monetary policy on the economy by weighting together changes in the exchange rate and interest rates, according to their relative effects on activity. The approach taken in this paper is to augment such an index with a broader set of financial variables. Numerous studies, some of which are summarised in Table 1, have constructed various financial conditions indices (FCIs) which attempt to provide a single summary measure of the overall stance of financial conditions. Most of these incorporate effects from asset prices as well as interest rates and the exchange rate. Survey measures of non-price credit conditions are not usually incorporated in the construction of such an FCI, although a recent exception is Swiston (2008).

\section{Econometric estimations underlying the construction of the financial conditions index}

6. The weight of each variable in the FCI is based on the estimated relative effect of a one-unit change in that variable on US GDP. Estimation was undertaken using two methods: a reduced-form equation for the output gap and an unrestricted vector auto-regression (VAR) to explain GDP growth. In both cases potential financial explanatory variables which were investigated included: real short-term interest rates, real long-term interest rates, the real effective exchange rate, various measures of bond

3. All these variables are known to have an impact of activity. There is abundant empirical evidence regarding the effect of interest rates, the exchange rate and asset prices on GDP or its component expenditures. There is also empirical evidence to show that bond spreads have significant explanatory power for the US business cycle (for example, Gertler and Lown, 2000, and Mody and Taylor, 2003). Moreover, recent work has found a significant impact of non-price credit standards, as measured by responses to the federal loans officer's survey, on US growth (Lown and Morgan, 2004, Estrella, 2004, and Deutsche Bank, 2008). 


\section{Table 1 Summary table of previous work to construct financial conditions indices}

\begin{tabular}{|c|c|c|c|}
\hline Study & $\begin{array}{l}\text { Countries } \\
\text { covered }\end{array}$ & $\begin{array}{l}\text { Financial variables } \\
\text { included }^{1}\end{array}$ & Comments \\
\hline Goldman Sachs (2000) & United States & Stock market capitalisation/GDP & $\begin{array}{l}\text { Weights based on GDP effects derived } \\
\text { from Fed's macro model }\end{array}$ \\
\hline Goodhart and Hofmann (2001) & Each of the G7 & $\begin{array}{l}\text { Real house prices, real equity } \\
\text { prices }\end{array}$ & $\begin{array}{c}\text { Alternative Financial Conditions Indice (FCl)'s } \\
\text { calculated both from reduced form and Vector } \\
\text { Auto Regression (VAR) estimation }\end{array}$ \\
\hline Gauthier, Graham, Liu (2004) & Canada & $\begin{array}{l}\text { Real housing prices, real US } \\
\text { equity prices, US high yield } \\
\text { spread }\end{array}$ & $\begin{array}{l}\text { Alternative FCl's calculated from } \\
\text { reduced form, VAR estimations } \\
\text { and factor analysis }\end{array}$ \\
\hline Mayes and Virén (2001) & $\begin{array}{l}11 \text { European } \\
\text { countries }\end{array}$ & $\begin{array}{l}\text { Real house prices, real asset } \\
\text { prices }\end{array}$ & Reduced form equations \\
\hline Swiston (2008) & United States & $\begin{array}{l}\text { Lending standards, corporate } \\
\text { bond yields, equity prices, } \\
\text { exchange rate }\end{array}$ & VAR estimations \\
\hline
\end{tabular}

1. In addition to (low-risk) interest rates and the exchange rate.

Source: OECD calculations.

spreads, stock market capitalisation and real housing wealth (the latter two variables are both expressed as a share of GDP and taken as the deviation from trend, following Goodhart and Hofmann, 2001). The estimations were carried out on quarterly data spanning the period 1990Q4 to 2007Q4. ${ }^{4}$

\section{Reduced-form estimation}

7. The series of estimated reduced-form equations for the output gap is tabulated in Table 2. The retained preferred specification, equation [5], is based on the reduced-form equation for the output gap explained by the real long-term interest rate, dynamic (i.e. temporary) effects from short-term interest rates, the real exchange rate, spreads on high-yield corporate bonds, stock market capitalisation and nonprice credit standards. The main findings from the reduced-form estimations are as follows:

- Both the federal funds rate and the 3-month euro-dollar rate were tested as alternative measures of short-term interest rates, and although highly collinear, the latter was generally preferred in estimation and so retained.

- Real long-term interest rates are measured relative to ten-year-ahead inflation expectations as from the Survey of Professional Forecasters by the Federal Reserve Bank of Philadelphia. When this variable is included no statistically significant effect from the level of short-term policy rates can be found, although a dynamic (change) term remains statistically significant (see equations [2] to [4]). This implies that beyond a very short horizon, long-term real interest rates have a stronger effect on activity than short rates.

4. The estimation period is limited by availability of data for the Federal Loan Officer Survey, which starts in 1990. 
ECO/WKP(2008)43

Table 2. Reduced form output gap equations,

Sample estimation period 1990 Q4 to 2007 Q4

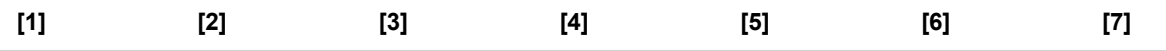

Dependent variable: $\triangle \mathrm{GAP}$

\begin{tabular}{|c|c|c|c|c|c|c|c|}
\hline $\operatorname{GAP}(-1)$ & $-0.124 * * *$ & $-0.114 * *$ & $-0.209^{* * *}$ & $-0.209 * * *$ & $-0.194 * * *$ & $-0.208^{* * *}$ & $-0.211 * * *$ \\
\hline RIRS(-1) & $-0.069 * * *$ & $-0.081 * * *$ & 0.001 & & & & \\
\hline$\Delta \mathrm{IRS}(-1)$ & $-0.322 * *$ & $-0.342 * *$ & $-0.315^{* *}$ & $-0.315^{* *}$ & -0.330 ** & -0.350 ** & -0.364 ** \\
\hline CSTAND(-2) & $-0.018^{* * *}$ & $-0.011^{* *}$ & $-0.017^{* * *}$ & $-0.017^{* * *}$ & $-0.010 * *$ & $-0.012 * * *$ & $-0.012^{* *}$ \\
\hline MKTCAP(-1) & 1.448 *** & $1.402 * * *$ & $1.840 * * *$ & $1.841^{\star \star *}$ & $1.763^{* * *}$ & $1.834^{* * *}$ & 1.992 *** \\
\hline $\operatorname{RIRL}(-3)$ & & & $-0.332 * * *$ & $-0.330 * * *$ & & $-0.387^{* * *}$ & \\
\hline \multicolumn{8}{|l|}{ SPREADB(-3) } \\
\hline$\triangle$ SPREADB $(-1)$ & & & & & & -0.248 * & \\
\hline $\begin{array}{l}\operatorname{HYSD}(-1) \\
\Delta \operatorname{HYSD}(-1)\end{array}$ & & $-0.100 * *$ & & & -0.096 ** & & -0.096 ** \\
\hline$\Delta D V_{-} R X(-1)$ & & & & & & & -3.361 \\
\hline$\Delta D V_{-} R X(-2)$ & & & & & & & -2.202 \\
\hline Adjusted R-squared & 0.444 & 0.474 & 0.429 & 0.439 & 0.472 & 0.461 & 0.481 \\
\hline S.E.of regression & 0.365 & 0.355 & 0.339 & 0.336 & 0.326 & 0.329 & 0.323 \\
\hline
\end{tabular}

Key to variables

GAP = Output gap.

IRS = Nominal 3-month.interest rates on euro-dollar deposits in London.

RIRS = Real short-term interest rates, IRS relative to inflation rate on core consumer prices.

CSTAND = Credit Standards, net \% of bank tightening standards for large and medium-sized firms (Federal Senior Loan Officer Survey)

MKTCAP = Deviation of stock market capitalisation, expressed as a ratio to GDP, from trend (Datastream and authors' calculations).

$\mathrm{RIRL}=$ Real long-term interest rates, defined as yield on 10-year government bonds relative to inflation expected over the following 10 according to

by the Survey of Professional Economists (Federal Reserve Board of Philadelphia).

HYSD = High yield bond spread (Datastream).

SPREADB = Corporate bond spread between Moody's Baa Corporate bonds and 10-year government bonds (Federal Reserve Board).

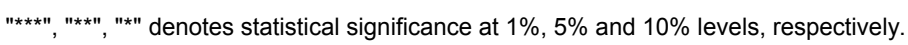

Sources: OECD Analytical Database unless otherwise specified.

- The coefficient on the credit standards variable $e^{5}$ is statistically significant, correctly signed and implies a substantial effect on GDP; a net 10 percentage points tightening in the survey response on lending conditions reduces GDP by about $1 / 4$ percentage point after four to six quarters. The

5. The Federal Loan Officers Opinion Survey provides responses on the number of banks tightening credit standards over a three-month period, so that, depending on how banks interpret the questionnaire, it does not necessarily provide an absolute measure of the credit standards rather than a measure of how they have changed. However, alternative functional forms of the survey responses, in which they were variously accumulated over time, invariably led to deterioration in goodness-of-fit in the empirical estimation. Cunningham (2006) expresses some scepticism about the information content of the loan officer survey responses, but this is mainly related to responses regarding consumer and real estate loan rather than those to businesses. 
magnitude of these effects is smaller, but not dissimilar to those obtained by Lown and Morgan (2004) and Swiston (2008). ${ }^{6}$

- The spread on Baa-rated corporate bonds and the high yield bond spread, both measured relative to ten-year Treasury bonds, are always correctly-signed and statistically significant when included separately in the reduced-form estimation, but due to collinearity between the variables it is difficult to find them both significant simultaneously. The high-yield bond spread is retained in the preferred reduced form.

- The real exchange rate variable is rarely statistically significant in estimation and is excluded from the preferred reduced-form specification.

- Stock market capitalisation has a strong well-determined effect in the reduced-from estimation, although significantly greater than suggested by back-of-the envelope calculations regarding a conventional wealth effect operating through consumption. The magnitude of this response may reflect problems of causality and simultaneity in the reduced-form estimation where it may be difficult to distinguish whether an increase in equity prices today is causing a future increase in activity (via a wealth effect) or is anticipating it (perhaps in response to some other financial news).

- Various measures of housing wealth were always statistically insignificant and/or incorrectly signed and so omitted. Other non-financial variables, including the oil price and a measure of the fiscal stance were also tested, but found to be insignificant and so omitted as well.

\section{Vector auto-regression estimation}

8. A potential advantage of the VAR over the reduced-form estimation in that it better takes into account the feedback between all variables, which may be particularly important when dealing with financial variables. The VAR includes GDP growth, core inflation and the same set of financial variables that were tested in reduced-form estimation. Oil prices are also included as an exogenous variable. The VAR is estimated on quarterly data and includes two lags for each variable.

9. Once the estimated VAR has passed standard tests for stability and normality of residuals, generalised impulse functions are calculated following the approach proposed by Pesaran and Shin (1998) (and used by Gauthier et al. (2004) in their construction of an FCI for Canada). This approach has the merit that responses to shocks are invariant to the ordering of the variables. This feature is especially important when dealing with financial series for which there is no clear theory-based ordering of the variables that could be used, for example, in a standard Choleski factorisation. Indeed, the impulse functions were found to be very sensitive to the ordering of financial variables when such an approach was adopted.

10. Several combinations of the financial variables were tried in the VAR, with the main findings being:

- The credit standards variable and the high-yield spread had a correctly-signed effect on GDP growth and in most estimations were statistically significant (to at least the $10 \%$ level); after four to six quarters this impact is of a similar magnitude to that obtained in the reduced-form

6. Lown and Morgan (2004) report a peak effect on GDP of $-0.5 \%$ for a shock to credit standards of 8 percentage points. Swiston (2008) finds in some specifications that a tightening in lending standards by 20 percentage points reduces GDP by $3 / 4$ per cent after one year and $1 \frac{1 / 4}{4}$ per cent after two years. 
estimation (Table 3). The high-yield spread was more significant than the spread on Baa corporate bonds.

Table 3. The estimated effects on GDP from shocks to financial variables

\begin{tabular}{|c|c|c|c|}
\hline \multirow[b]{3}{*}{ Real short-term interest rates } & \multirow[b]{2}{*}{ Shock } & \multicolumn{2}{|c|}{$\begin{array}{l}\text { Effect on GDP }(\%) \\
\text { after 4-6 quarters }\end{array}$} \\
\hline & & $\begin{array}{l}\text { Reduced form } \\
\text { equation }\end{array}$ & VAR \\
\hline & $\begin{array}{l}100 \text { basis point } \\
\text { increase }\end{array}$ & -0.18 & -0.16 \\
\hline Real long-term interest rates & " & -0.59 & -- \\
\hline High yield bond spread & " & -0.28 & -0.20 \\
\hline Credit standards tightening & $\begin{array}{l}10 \text { percentage point } \\
\text { increase }\end{array}$ & -0.26 & -0.26 \\
\hline Real exchange rate & $"$ & - & -1.00 \\
\hline $\begin{array}{l}\text { Stock market capitalisation } \\
\text { (ratio to GDP, de-trended) }\end{array}$ & " & 0.52 & 0.10 \\
\hline
\end{tabular}

- Real short-term interest rates had a correctly-signed impact on GDP after four to six quarters, but while the magnitude of this effect was similar to that obtained from the reduced-form equation it was often not statistically significant. Real long-term rates had a correctly-signed effect on GDP after four to six quarters, but this was much smaller than the corresponding effect in the reducedform equation and again not statistically significant. In addition, the significance of other financial variables tended to diminish when real long term rates were introduced. Consequently, the preferred VAR specification does not include real long-term interest rates.

- The real effective exchange variable was correctly signed but not always statistically significant, and its estimated impact on GDP is somewhat larger than obtained from other estimates such as those of Swiston (2008) or those based on macroeconomic models of the US economy.

- Stock market capitalisation was found to have a positive, but in most cases weakly significant impact on GDP.

- Thus, in addition to GDP growth, core inflation and oil prices, the preferred VAR specification includes the following financial variables: real short-term interest rates, the high-yield bond spread, non-price credit standards, the real exchange rate and stock market capitalisation. The generalised impulse responses are shown in Figure 2. 
Figure 2. Response of the level of GDP to financial variables in the preferred VAR ${ }^{1}$

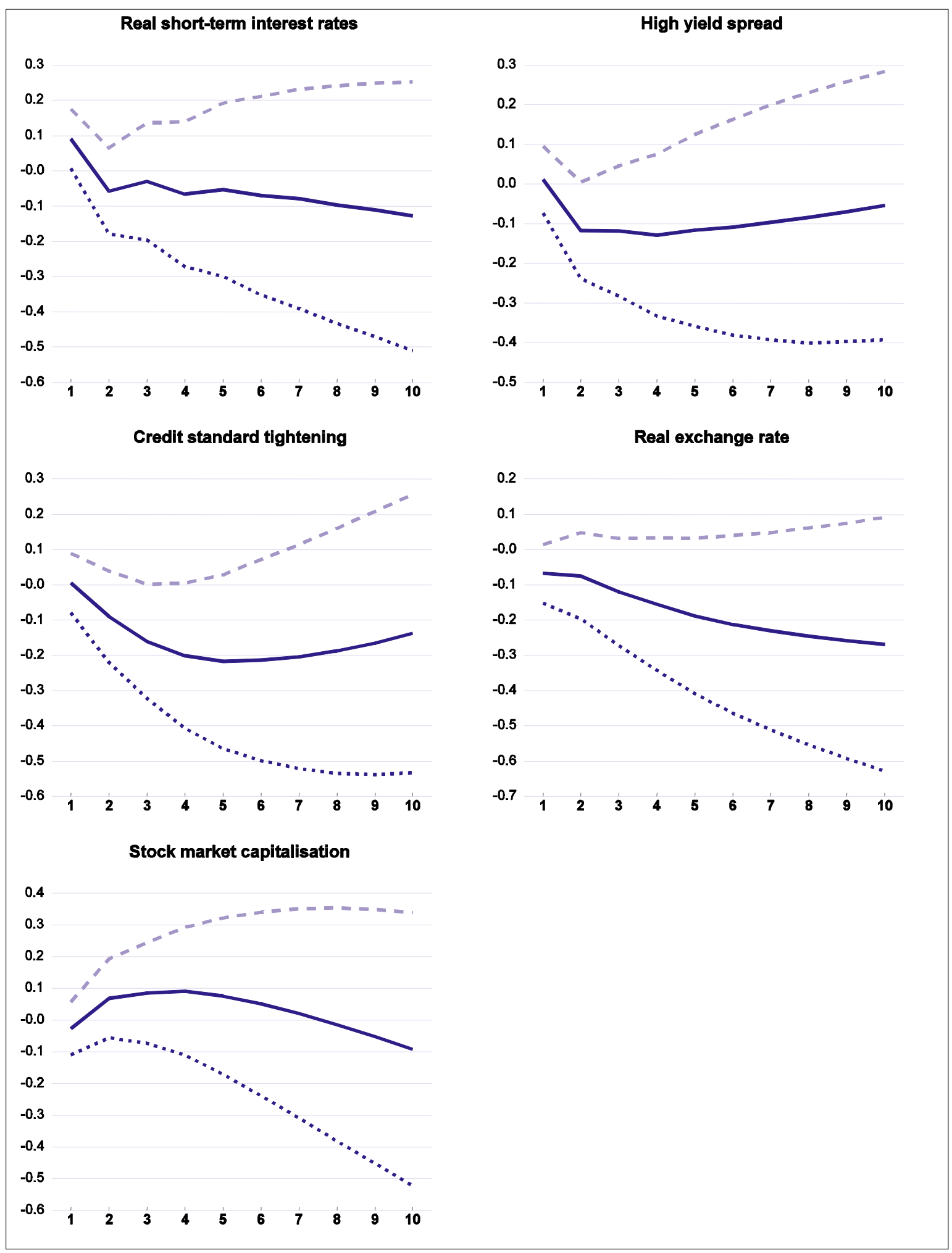

1. Accumulated response of quarterly GDP growth to generalised one standard innovation shocks to financial variables.

Note: Dotted lines denote +/- 2 standard errors (close to $5 \%$ significance boundaries). For precise definition and source of variables see notes to Table 2. 


\section{Summary of the results}

11. The estimated average effect on the level of GDP after four to six quarters following a shock to each financial variable is reported in Table 3 for the preferred specification from both the reduced form and VAR.

12. The main points of similarity and difference across the two estimation procedures are as follows:

- The non-price measure of credit availability has a significant, correctly signed and similar effect in both; a net 10 percentage points tightening in the survey response on lending conditions reduces GDP by about $1 / 4$ percentage point after four to six quarters. The magnitude of these effects is smaller, but not dissimilar to those obtained by Lown and Morgan (2004) and Swiston $(2008){ }^{7}$

- The magnitude of the effect of real long-term interest rates on GDP is more than three times stronger in the reduced-form estimation than the VAR, where it is not even statistically significant. Moreover, while the magnitude of the effect of real short-term interest rates on GDP is similar across the two estimation procedures, it is not statistically significant in the VAR. Given that the weights used in the construction of the FCI are specified relative to the effect of interest rates, and these effects are poorly determined when using the VAR approach, the reduced form has been chosen as the basis for the preferred FCI.

\section{The construction of the financial condition index}

13. Weights of the variables in the FCI (Table 4) are based on the relative effect of a one unit change in the relevant variable on GDP, evaluated as the average effect on the level of GDP after four to six quarters, a horizon chosen because of its relevance to monetary policy. All weights are normalised on the

Table 4. The weights used to construct the financial condition index

\begin{tabular}{|c|c|c|c|}
\hline & & $\begin{array}{r}\text { Weights used in c } \\
\text { inde }\end{array}$ & nstruction of \\
\hline & $\begin{array}{l}\text { Standard } \\
\text { deviation, } \\
\text { 1990-2007 }\end{array}$ & $\begin{array}{l}\text { OECD Monetary } \\
\text { Conditions Index } \\
\text { (MCI) }\end{array}$ & $\begin{array}{c}\text { Financial } \\
\text { Conditions } \\
\text { Index (FCl) }\end{array}$ \\
\hline Real short-term interest rates (\%) & 1.74 & 1.00 & 0.29 \\
\hline Real long-term interest rates (\%) & 1.21 & & 1.00 \\
\hline High yield bond spread (\%) & -0.20 & & 0.47 \\
\hline Credit standards tightening (\%) & 21.5 & & 0.04 \\
\hline Real exchange rate (\%) & 0.08 & 0.15 & $0.15^{1}$ \\
\hline $\begin{array}{l}\text { Stock market capitalisation } \\
\text { (ratio to GDP, de-trended) (\%) }\end{array}$ & 0.21 & & -0.03 \\
\hline 1. Indicates an imposed coefficient. & & & \\
\hline & & & \\
\hline
\end{tabular}

7. Lown and Morgan (2004) report a peak effect on GDP of $-0.5 \%$ for a shock to credit standards of 8 percentage points. When long-term rates are not included in the VAR the impact is $-0.3 \%$ 
effect of a change in real long-term interest rates, so that a unit increase in the index has the same effect on GDP as an increase in real long-term interest rates of 100 basis points. Because of the problems of simultaneity and causality which may particularly bias the weight of the stock market variable from the reduced form, the weight has instead been calibrated on the basis of a " $3 \frac{1}{2}$ cents" wealth effect on consumption (similar to that operating in the Federal Reserve's FRB/US model). A weight of 0.15 has also been imposed on the real exchange rate, which is the weight that has been used by the OECD in the calculation of a Monetary Conditions Index and is derived from large-scale macro model simulations. The index is re-normalised so that its average value over the full sample period is zero.

14. The index and its decomposition since 1995 are shown in Figure 3, with the main financial variables projected to give values for 2008Q3. ${ }^{8}$ The index suggests that during the second half of 2007 the implications of the credit crunch for economic activity may have been broadly offset by lower interest rates on government paper and the depreciation of the dollar. However, during 2008 the continued tightening in non-price credit standards and the increase in spreads for riskier borrowers have implied a trend worsening in financial conditions.

Figure 3. The financial conditions index

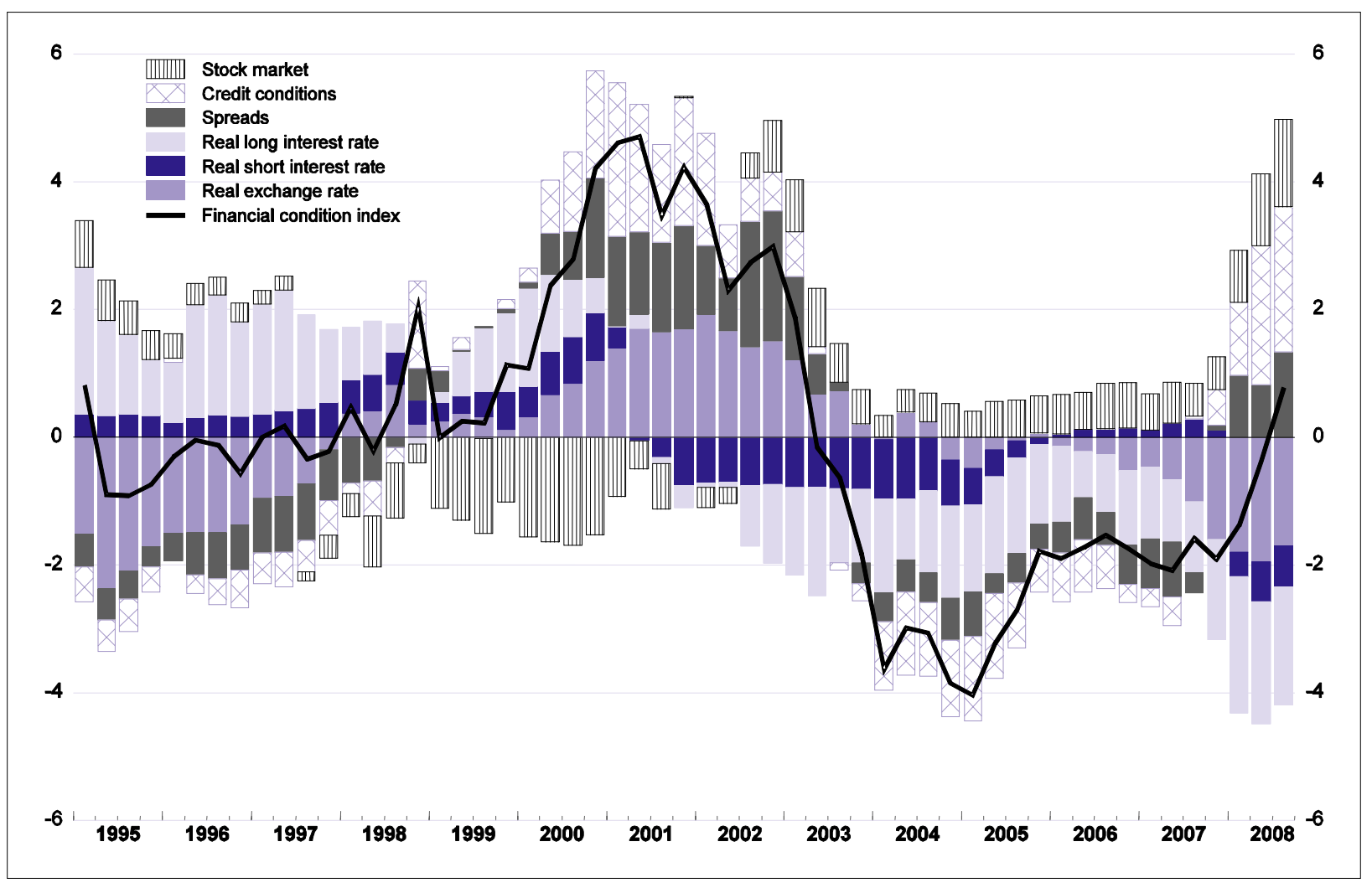

Note: A unit increase in the index corresponds to an effect on GDP equivalent to an increase in real long-term interest rates of 100 basis points.

8. Data on interest rates and spreads up to the 21 August are then extrapolated to give values for the third quarter of 2008. For the third quarter the OECD's measure of the real effective exchange rate is extrapolated using the Federal Reserve's measure of the broad effective dollar exchange rate. 
15. The overall tightening of the FCI since the second quarter of 2007 is estimated to be equivalent to an increase in real long-term interest rates of 280 basis points and could reduce GDP by 1.7 percentage points over the coming four to six quarters (Table 5). While the tightening of credit standards combined with higher spreads and lower share prices could remove nearly $3 \%$ of GDP over the coming four to six quarters, this negative impact is partly compensated by lower short- and long-term interest rates and dollar depreciation. Overall, this would suggest that not only have financial conditions continued to deteriorate into the third quarter of 2008, but that the implications for real activity have just begun to be felt.

Table 5. Accounting for the tightening in financial conditions since the onset of the financial turmoil

\begin{tabular}{|c|c|c|c|}
\hline $\begin{array}{l}\text { Component of the } \\
\text { Financial Conditions Indice (FCI) }\end{array}$ & $\begin{array}{c}\text { Change } \\
2007 \text { Q2 to } \\
2008 \text { Q3 }^{1}\end{array}$ & $\begin{array}{l}\text { Contribution } \\
\text { to change } \\
\text { in } \mathrm{FCl}\end{array}$ & $\begin{array}{c}\text { Estimated effect } \\
\text { on GDP after } \\
\text { 4-6 quarters }\end{array}$ \\
\hline Net percentage of banks tightening standards & 61.3 & 2.7 & -1.6 \\
\hline $\begin{array}{l}\text { Change in high yield spreads } \\
\text { (percentage points) }\end{array}$ & 4.6 & 2.2 & -1.3 \\
\hline $\begin{array}{l}\text { Change in stock market capitalisation as a } \% \\
\text { of GDP (percentage points of GAP) }\end{array}$ & -0.2 & 0.7 & -0.4 \\
\hline Total negative factors & & 5.6 & -3.3 \\
\hline $\begin{array}{l}\text { Change in real short-term interest rates } \\
\text { (percentage points) }\end{array}$ & -3.0 & -0.9 & 0.5 \\
\hline $\begin{array}{l}\text { Change in real long term interest rates } \\
\text { (percentage points) }\end{array}$ & -0.9 & -0.9 & 0.5 \\
\hline Change in real exchange rate $(\%)$ & -6.9 & -1.0 & 0.6 \\
\hline Total supportive factors & & -2.8 & 1.7 \\
\hline Total & & 2.8 & -1.7 \\
\hline $\begin{array}{l}\text { 1. } 2008 \text { Q3 is estimated. } \\
\text { Source: OECD calculations. }\end{array}$ & & & \\
\hline
\end{tabular}

16. As a sensitivity check an alternative FCI has been constructed using results from the VAR impulse function. For reasons of comparability this alternative FCI is normalised so that a unit change in the index has the same effect on GDP as a unit change in the FCI derived from the reduced form. The tightening in financial conditions over the last year is similar across both measures, as shown in Figure 4. This tightening stands in marked contrast to the loosening of a more narrow measure of monetary conditions. In this respect the current episode is unusual -- usually broad financial conditions and narrow monetary conditions have tended to move in the same direction. 
Figure 4. A comparison of financial and monetary condition indices

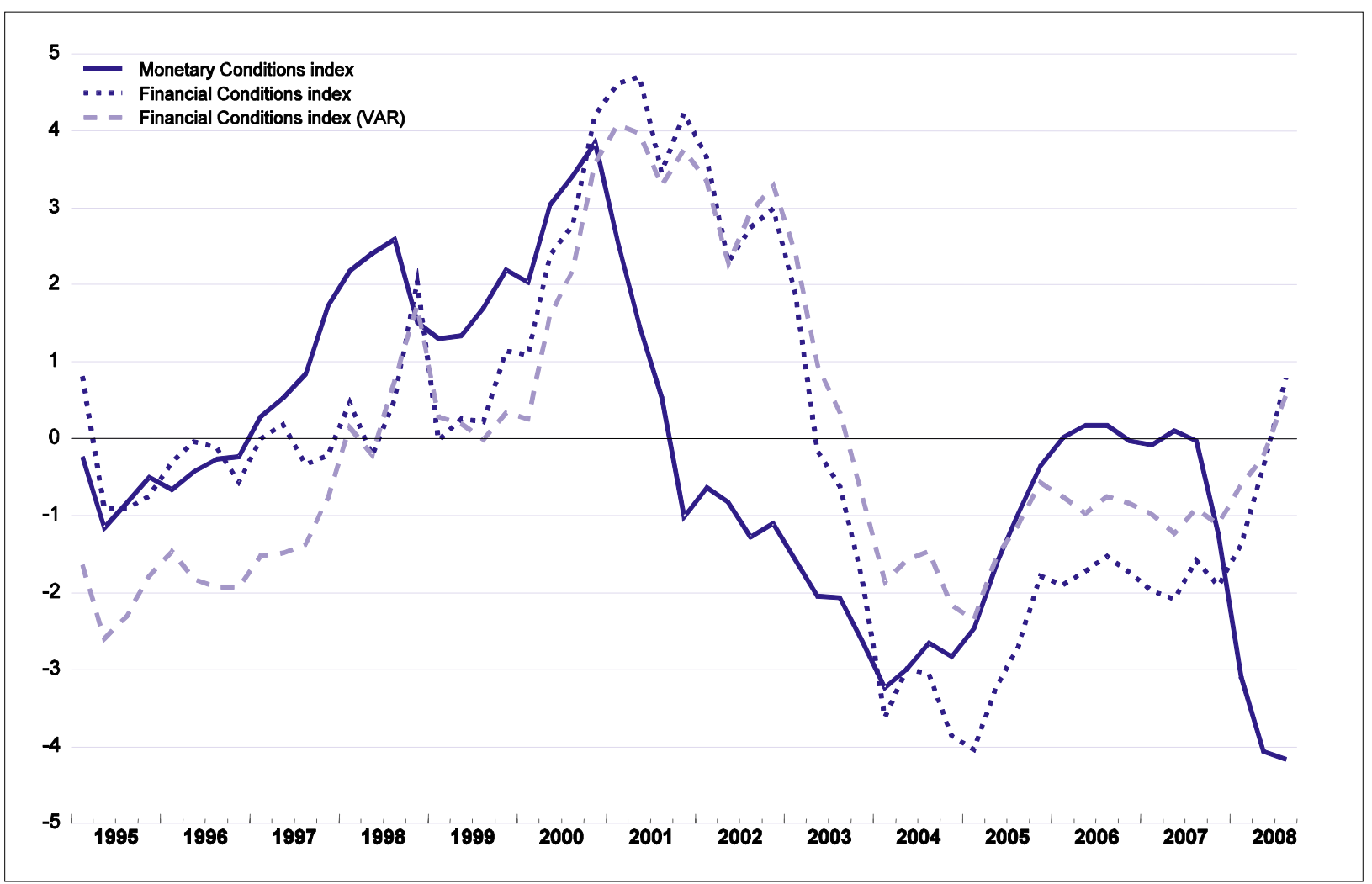

Note: For details of the construction of the financial condition indices see main text. The monetary conditions index is a weighted average of real short-term interest rates and the real exchange rate, with relative weights of 1.0 and 0.15 . All indices are expressed as deviations from the sample average. 
ECO/WKP(2008)43

\section{BIBLIOGRAPHY}

Cunningham, T. (2006), "The Predictive Power of the Senior Loan Officer Survey: Do Lending Officers Know Anything Special?”, Federal Reserve Bank of Atlanta, Working Paper, No. 2006-24.

Deutsche Bank (2008), “Tighter Bank Lending Standards Are Hurting the US Economy”, DB Global Economic Perspectives, 4 February.

Dudley, W. and J. Hatzius (2000), "The Goldman Sachs Financial Conditions Index: the Right Tool for a New Monetary Policy Regime”, Goldman Sachs Global Economics Paper, No. 44.

Estrella, A. (2004), "Banks and Monetary Transmission in the Current U.S. Environment", Presented at the $25^{\text {th }}$ SUERF Colloquium on "Competition and Profitability in European Financial Services: Strategic, Systematic and Policy Issues", Madrid, 14-16 October.

Gauthier C., C. Graham and Y. Liu (2004), "Financial Conditions Indexes for Canada”, Bank of Canada Working Paper, No 2004-22.

Gertler, M, and C. Lown (2000), "The Information in the High Yield Bond Spread for the Business Cycle: Evidence and Some Implications", NBER Working Paper, No. 7549.

Goodhart, C. and B. Hofmann (2001), "Asset Prices, Financial Conditions, and the Transmission of Monetary Policy", Paper Presented at the Conference on 'Asset Prices, Exchange Rate, and Monetary Policy', Stanford University (2001), March.

Lipworth, G. and G. Meredith (1998), "A Reexamination of Indicators of Monetary and Financial Conditions", in Aghevli, B., T. Bayoumi and G. Meredith (eds), Structural Change in Japan: Macroeconomic Impact and Policy Challenges, IMF, Washington, DC.

Lown, C. and D. Morgan (2004), "The Credit Cycle and the Business Cycle: New Findings Using the Loan Officer Opinion Survey", Research report from Stockholm Institute for Financial Research, No. 27, September.

Mayes, D. and M. Viren (2001), "Financial Conditions Indexes", Bank of Finland Working Paper, No. $17 / 2001$.

Muellbauer, J., (2007), "Housing, Credit and Consumer Expenditure”, FRB/Kansas City Symposium on Housing, Housing Finance and Monetary Policy, Jackson Hole, WY, 31 August to 1 September.

Mody, A., and M. Taylor (2003), "The High-Yield Spread as a Predictor of Real Economic Activity: Evidence of a Financial Accelerator for the United States", IMF Staff Papers, Vol. 50, No. 3.

Swiston, A. (2008), “A US Financial Conditions Index: Putting Credit Where Credit is Due”, IMF Working Paper, No. WP/08/161. 
$\mathrm{ECO} / \mathrm{WKP}(2008) 43$

\section{WORKING PAPERS}

The full series of Economics Department Working Papers can be consulted at www.oecd.org/eco/Working_Papers/

634. Have long-term financial trends changed the transmission of monetary policy (September 2008), Stéphanie Guichard and David Turner

633. Raising education achievement and breaking the cycle of inequality in the United Kingdom (August 2008) Anne-Marie Brook

632. The euro changeover in the Slovak Republic: implications for inflation and interest rates (August 2008) Felix Hüfner and Isabell Koske

631. Tax reform for efficiency and fairness in Canada (August 2008) Alexandra Bibbee

630. Reforming the Polish Tax System to Improve its Efficiency (August 2008) Alain de Serres

629. Modernising Canada's Agriculture Policies (August 2008) Peter Jarrett and Shuji Kobayakawa

628. Recent trends and structural breaks in US and EU15 labour productivity growth (August 2008) Laure Turner and Hervé Boulhol

627 Health Status Determinants: Lifestyle, Enviroment, Health Care Resources and Efficiency (August 2008) Isabelle Joumard, Christophe André, Chantal Nicq and Olivier Chatal

626. Market Mechanisms in Public Service Provision (August 2008) Hansjörg Blöchliger

625. Improving human capital formation in India (July 2008) Sean S. Dougherty and Richard Herd

624. Labour regulation and employment dynamics at the state level in India (July 2008) Sean S. Dougherty

623. India's growth pattern and obstacles to higher growth (July 2008) Sean S. Dougherthy, Richard. Herd, Thomas. Chalaux and Abdul. Erumban

622. Reaping the benefits of stronger competition in network industries in Germany (July 2008) Nicola Brandt

621. The Usefulness of Output Gaps for Policy Analysis (July 2008) Isabell Koske and Nigel Pain

620. Taxation and Economic Growth (July 2008) Åsa Johansson, Christopher Heady, Jens Arnold, Bert Brys and Laura Vartia 
619. Coping with labour shortages: How to bring outsiders back to the labour market (July 2008) Ekkehard Ernst

618. Achieving sustainability of the energy sector in Canada (June 2008) Annabelle Mourougane

617. The Dutch tax-benefit system and life-cycle employment. Outcomes and reform options (June 2008) Ekkehard Ernst and Timo Teuber

616. Regulation, Allocative Efficiency and Productivity in OECD Countries: Industry and Firm-Level Evidence

(May 2008) Jens Arnold, Giuseppe. Nicoletti, and Stefano Scarpetta

615. Public social spending in Korea in the context of rapid population ageing (May 2008) Randall S. Jones

614. Enhancing the globalisation of Korea (May 2008) Randall S. Jones and Taesik Yoon

613. Reforming housing and regional policies in Korea (May 2008) Randall S. Jones and Tadashi Yokoyama

612. Moving towards more sustainable healthcare financing in Germany (May 2008) N. Brandt

611. Improving education outcomes in Germany (May 2008) David Carey

610. Have developed countries escaped the curse of distance? (May 2008) Hervé Boulhol and Alain de Serres

609. Measures of international transport cost for OECD countries $\mid$ (April 2008) Stephen S. Golub and Brian Tomasik

608. Encouraging labour force participation in Chile (April 2008) D. Contreras, L. de Mello and E. Puentes

607. Tackling business and labour informality in Chile (April 2008) D. Contreras, L. de Mello and E. Puentes

606. Delivery cost-efficient public services in health care, education and housing in Chile (April 2008) D. Contreras, L. de Mello and E. Puentes

605. Managing Chile's macroeconomy during and after the copper price boom (April 2008) Luiz de Mello

604. Avoiding the value added tax: Theory and cross-country evidence (April 2008) Luiz de Mello 